10IKC-347

\title{
INTEGRATION OF GEOPHYSICAL AND GEOLOGICAL DATA OF KIMBERLITES IN NARAYANAPET - MADDUR FIELD, ANDHRA PRADESH, INDIA
}

T.Vani1 *, V.Naga Lakshmi1, M.V.Ramakrishnarao ${ }^{2}$, G. Randy Keller ${ }^{3}$ and K.V.Subbarao ${ }^{4}$

1. University Centre for Earth and Space Sciences, University of Hyderabad, Gachibowli, Hyderabad - 500046, India

2. M.V.Ramakrishnarao, H.No.8-28/5, Sri Sai Krishna Nagar Colony, Phase - IV, B/s. Tirumal Padmavathi Function Hall, Hyderabad - 500039, India

3. G. Randy Keller, Mewbourne College of Earth \& Energy, University of Oklahoma, Suite N131, Sarkeys Energy Center, Norman, Oklahoma - 73019-0628, USA

4. Centre for Modelling Simulation and Design, University of Hyderabad, Gachibowli, Hyderabad - 500046, India

The Archean Dharwar craton of India hosts well known kimberlite fields. The present study area is in the Narayanpet-Maddur of South India (Fig. 1; Rao et al. 2001), which is a part of the eastern Dharwar craton with $\sim 32$ kimberlites $(1400-1080 \mathrm{Ma})$ forming three clusters. Geological and geophysical studies reflect the tectonically complex nature of the area. Based on LISS III satellite imagery, the area of study reveals

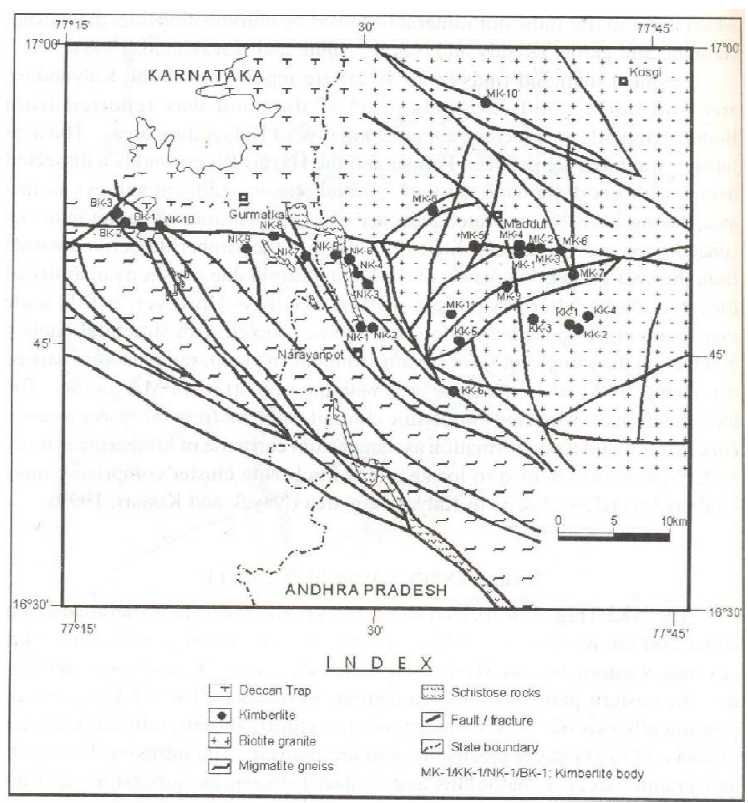

Fig 1. Geological map of Narayanpet - Maddur area (after Rao et al. 1998) the presence of domal structures coupled with large synform structures that trend NW-SE and dykes that strike in several directions (NW - SE $\& \mathrm{E}-\mathrm{W})$.

Bouguer gravity anomalies vary from -68.6 to -86.1 mgal (Fig.2) and the general range of magnetic anomalies lies between 184 and -241 nT. These show subsurface structures in the area depending on the density and susceptibility variations respectively. The eastern and western parts of the study area are covered by biotite granite and migmatite gneiss that are separated by a prominent NW - SE trending schist belt that is expressed in both the gravity and magnetic data. This is in contrast with the geological map where in schistose rocks occur as narrow bands within the migmatite gneiss, but not at the contact between biotite granite and migmatite gneiss.

The schist belt is interpreted as a locus for basement faulting. Maximum values of gravity anomalies coincide with the axis of the schist belt, where the schist belt attains considerable thickness in the subsurface as shown in the central Zimbabwe Archean craton (Ranganai et al 2008). Prominent NW - SE trending deep-seated faults are clearly delineated in both the geophysical maps. Faults / fractures extending for several kilometers are also evident in upward continuation 
represent a steep gravity gradient that suggests a sub-vertical contact; but on the eastern margin, NW-SE trending contours turn to the NE, suggesting multiple events of fracturing / faulting. Along with NW-SE trending major faults, E-W, NE-SW \& N-S linear trends indicate structural disturbances and the intersections of lineaments are likely favorable locations for the emplacement of the kimberlites. The second order gravity features in the form of contour deflections trending ENE - WSW to the NW of Narayanpet that may reflect transverse faults (Sreerama Murthy et al. 1999).

Magnetic anomalies are more effective in the identification of faults, fractures, and dykes in granitic terrains. Application of various digital filters to the geophysical data enhances the shallow and deeper subsurface features. For example, the magnetic anomaly map reduced to equator (Fig.3), clearly brought out the lithologic boundary between the biotite granite and migmatite gneiss and a distinct NW - SE trend of

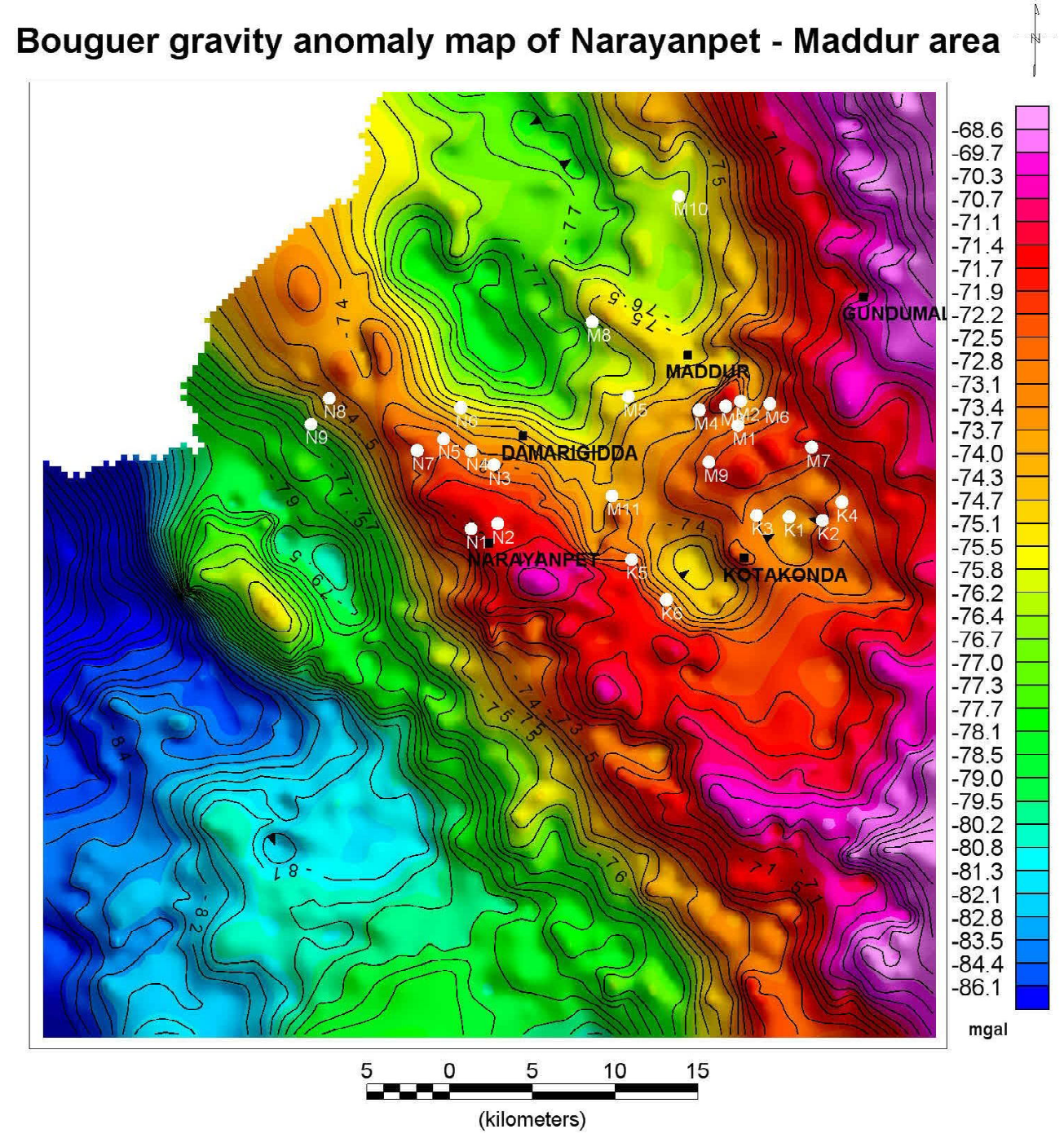

Fig 2. Bouguer gravity anomaly map of Narayanpet - Maddur area 


\section{$10^{\text {th }}$ International Kimberlite Conference, Bangalore - 2012}

the gneiss bounded by a set of parallel faults. Similarly, the narrow belt of schistose rocks is clearly delineated in the gravity residual anomaly map by a high gravity linear trend (NW-SE) in conformity with the geological map. Secondly, in the NE around Maddur and Kotakonda, a prominent gravity low is surrounded by gravity highs, and faulting is clearly seen in the gravity residual map suggesting the presence of granite diapers. The analytical signal map demarcates the weathered and unweathered pipes depending on the intensity of magnetization.
Gravity and magnetic 2D forward modeling of profiles across the Narayanpet, Maddur and Kotakonda clusters reveal intrusive bodies in the host rock and the structural disturbance of the area. These models correlate in terms of the subsurface geology and depths. Euler deconvolution depth estimation (gravity and magnetic) brought out the location and depth of dykes as well as a potential new kimberlite areas to the north of Maddur and in the NW and SE portions of schist belt at the contacts with the migmatite gneiss. These potential areas lie within

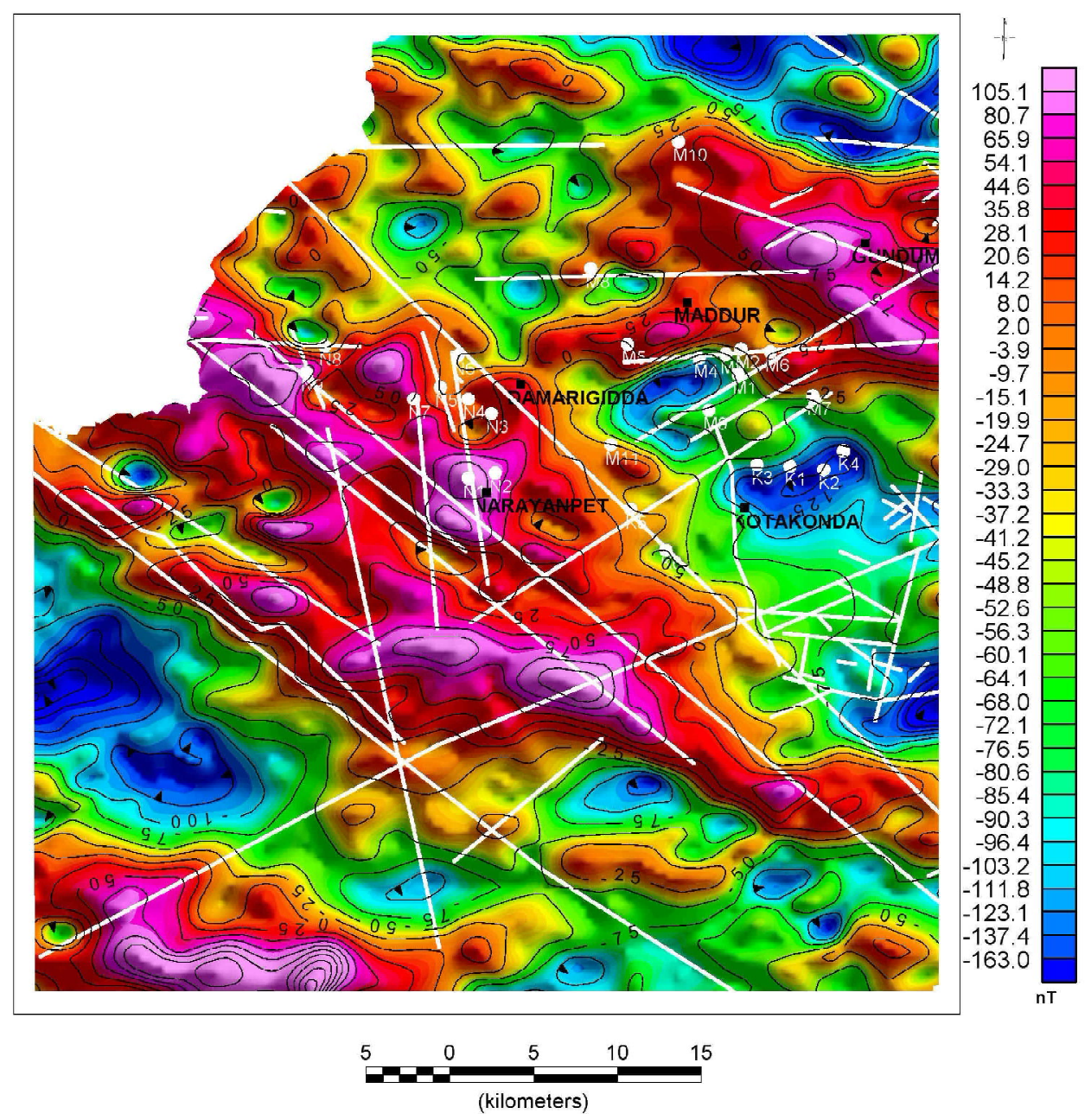

Fig 2. Magnetic anomaly map - reduced to equator - upward continuation $0.5 \mathrm{~km}$. White lines represent inferred faults from LISS III data. 


\section{0 $^{\text {th }}$ International Kimberlite Conference, Bangalore - 2012}

a conjugate system of fractures and faults (perhaps-some are rejuvenated).

We will present an integrated picture of geophysical and geological modeling to aid in exploration and also comment on apparent absence of diamonds using mantle compositions vis-a-vis Rare Earth Element (REE) geochemical inversion modeling.

\section{References:}

Rao, K.R.P., Reddy, T.A.K., K.V.S., Rao, K.S.B. and Rao, N.V. (1998) Geology, petrology and geochemistry of Narayanpet kimberlites in Andhra Pradesh, Jour. Geol. Soc. India, v. 52, pp. 663-676.

Ranganai, R.T., Whaler, K.A. and Ebinger. C.J. (2008) Gravity anomaly patterns in the south - central Zimbabwe Archean craton and their geological interpretation, Science Direct, Jour. of African Earth Sciences, v. 51, pp. 257-276.

Sreerama Murthy, N., Ananda Reddy, R., Rao, M.V.R.K., Sunder Raj, B., Murthy. N.V.S. and Vittal Rao, K.P.R. (1999) A new kimberlite discovery from a structural elucidation of gravity data, Maddur - Narayanpet field, Mahabubnagar district, Andhra Pradesh, Jour. of Geophysics, v. XX No. 1, pp. 3-13. 